\title{
Equity Financing and External Contracting at Biotech Firms: Evidence from PIPEs
}

\author{
Christopher W. Anderson ${ }^{1}$ \& Ying Jenny Zhang ${ }^{2}$ \\ ${ }^{1}$ School of Business, University of Kansas, Lawrence, Kansas, USA \\ ${ }^{2}$ College of Business, Missouri State University, Springfield, Missouri, USA \\ Correspondence: Ying Jenny Zhang, College of Business, Missouri State University, Springfield, MO 65897 , \\ USA. Tel: 1-417-836-5348. E-mail: yJennyZhang@MissouriState.edu
}

Received: November 21, 2014

Accepted: December 16, 2014

Online Published: January 25, 2015

doi:10.5539/ijef.v7n2p1

URL: http://dx.doi.org/10.5539/ijef.v7n2p1

\begin{abstract}
We investigate young public biotechnology companies that raise additional capital utilizing offerings of private investments in public equity-so-called PIPE deals. Among 110 biotech firms that raise $\$ 5.5$ billion in IPO proceeds during 1996 to 2004, 61 firms raise an additional \$9.5 billion from 200 PIPE deals by the end of 2006 . We study the timing and terms of such private placements in relation to biotech firms' external contracting activity. We hypothesize that firms raise new capital following good news such as advancement of clinical trials, signing of external contracts, and strong stock performance. We find that issuing firms with greater dollar volume of external contracting obtain better terms as manifested by lower offer discounts in PIPE deals involving common equity. These results suggest that investors incorporate information on external contracting activity when pricing and providing equity capital to cash-hungry biotech firms.
\end{abstract}

Keywords: PIPE, private equity financing, biotech, contracting

\section{Introduction}

Since the mid-1990s publicly traded companies have increasingly raised capital by means of security offerings involving private investments in public equity, so-called PIPE deals. Specifically, Sagient Research reports that more than ten thousand PIPE deals raised \$172 billion dollars for US firms from 1995 through June 2007. PIPE deals are frequently negotiated and completed in a matter of weeks, and such deals typically involve only a few participating investors and the issuing firm. After the deal is closed and the securities are placed the firm commits to register the newly issued securities with the SEC, and the privately issued securities are then later tradable in the public secondary markets after SEC review and approval (Hogboom, 2004) (Note 1). Public security offerings, in contrast, are subject to higher regulatory scrutiny and are often more expensive for the issuing firm in terms of direct issuance costs. Investors in PIPE deals are generally financial institutions such as hedge funds, private equity funds, venture capital funds, or other corporations. Public firms that finance with private placements tend to be small and are plagued by severe information asymmetries that impede valuation by outside investors. Such firms, consequently, have limited access to relatively costly public capital (Wruck, 1989; Hertzel \& Smith, 1993; Wu, 2004; Gomes \& Phillips, 2012; Chaplinksy \& Haushalter, 2010).

In this study we investigate financing activity via PIPE deals for young biotech firms. Young biotech firms fit the profile for PIPE financing extremely well. Most young firms in this sector are still in the developmental stage, do not have commercial products or tangible assets, and burn through cash reserves at a rapid pace. Firm value for such firms is almost entirely attributable to intangible assets such as the risky growth opportunities imbedded in the firm's research and development activities rather than assets in place or cash flows generated by currently marketed pharmaceutical products or medical devices. Furthermore, young biotech firms rely intensively on the capital markets and cash-generating contracting work with large and more established pharmaceutical companies in order to obtain cash to sustain daily operations and work toward strategic objectives such as conducting clinical trials and obtaining U.S. Food and Drug Administration approval to advance drugs to commercialization (Robinson \& Stuart, 2006). In particular, the drug development process is long and highly risky, and the FDA has rigorous requirements for drug approval. Perhaps only one in a thousand compounds ever tested as a potential drug candidate is eventually commercialized, and it takes eight to twelve years to bring a new chemical entity from the laboratory to the market as a new drug. The cumulative average cost of bringing a single drug to market 
has risen steadily in recent years, and a recent estimate exceeds $\$ 1$ billion per successful drug compound (Henderson, 2006). Investment activity by developmental firms also seems prone to problems of moral hazard, as young companies without developed products appear prone to over-investment in risky gambles with investor funds (Guedj \& Scharfstein, 2004). Indeed, many young biotech firms incur substantial costs with investors' funds without any eventual return (Note 2).

The importance of PIPE financing to these young biotech firms is exemplified by the following paragraph from the annual report for year 2002 for the firm Ardea Biosciences, which went public in 2000 (Note 3).

"Since commencing operations in 1994, we have not generated any revenue from product sales, and we have funded our operations primarily through the private sale of equity securities, including a private placement of 5.9 million shares of common stock resulting in net proceeds of approximately $\$ 13.9$ million in February 2002, a settlement of $\$ 3.6$ million from a vendor in January 2002, funds received from a terminated collaboration agreement, the proceeds of equipment financing arrangements and our initial public offering of common stock in March 2000. We have incurred losses in each year since inception, and we expect to incur substantial losses for at least the next several years. We expect that losses may fluctuate, and that such fluctuations may be substantial. As of December 31, 2002, our accumulated deficit was approximately \$200.3 million. We will need to raise additional funds in the future to continue our operations."

Consistent with this example, we find that PIPE financing is an important source of funds to young firms in the biotech sector. Specifically, we examine a comprehensive sample of 110 biotech firms that experienced their initial public offerings from mid-1996 through 2004, raising more than $\$ 5.5$ billion in IPO proceeds. Of these 110 firms, 61 arranged nearly \$9.5 billion in 200 PIPE deals in subsequent years through 2006.

Prior academic research suggests that an understanding of contracting activity among biotech firms is critical to understand financing activity (Robinson \& Stuart, 2006, 2007; Lerner, Shane, \& Tsai, 2003). We find that our sample firms were parties to a cumulative total of 1,969 external contracts with other firms over 1990 to 2006. These external contracts involve agreements to provide or be provided research and development, to license products or technology, or to engage in other collaborations with other sector firms, especially large mature pharmaceutical firms, and such contracts are often a vital source of cash to biotech firms. The cumulative nominal value assigned to these contracts by the consulting firm Recombinant Capital was nearly $\$ 70$ billion (Note 4).

We next focus on financing terms of PIPEs as measured by the offer price relative to the price of public securities. Shares of stock obtained via PIPEs and other forms of private placement are typically offered at discounts to prevailing market prices, and various studies investigate explanations the prevalence and magnitude of discounts (Wruck, 1989; Hertzel \& Smith, 1993; Barclay, Holderness, \& Sheehan, 2007). In particular, Hertzel and Smith (1993) note that PIPE investors must scrutinize an offering firm's business conditions before committing capital investment; the PIPE share discount compensates the investors' for their due diligence costs incurred prior to accepting the PIPE terms. Other factors that may explain PIPE discounts include share price volatility and liquidity, which can be viewed as costs of ownership for the private investors, and prior share price performance, which can be viewed as whether the firm has recently experienced bad news or poor performance and consequently has more difficulty in obtaining external capital through more traditional means such as an SEO or a debt offering. An advantage of focusing on the biotech industry - other than the heavy use of PIPE financing in this sector - is that measurement issues due to industry heterogeneity in common measures of information asymmetries (e.g., stock price volatility) in broad samples can be avoided. Furthermore, measures specific to the biotech industry can be employed. In particular, we use external contracting activity with other biotech firms as a proxy for the growth opportunities and business prospects of developmental firms. We measure the strength of firms' contracting network by number, type, and total size of their external contracts, and then investigate if contracting activity observed prior to the PIPEs deal conditions the offer price discount. Consequently, we study how the contracting activity of our sample firms affects financing terms in PIPE deals, which directly addresses the crucial issue of the firms' cost of capital.

We find that the discount at which PIPE securities are priced relative to publicly traded securities is inversely related to recent stock performance relative to a biotech stock index and the dollar amount of contracting work obtained over the prior year. These finding suggests that better market perception of the issuing firm and a more valuable contracting network lower the cost of external equity financing via PIPE deals. This study furthers our understanding of financial contracting in the biotech sector and how it is linked to operational contracting with other pharmaceutical industry firms. In particular, Lerner, Shane, and Tsai (2003) show that biotech firms rely more heavily on contractual alliances with large cash-rich pharmaceutical companies (so-called Big Pharma) to 
finance product development when external capital is scarce and costly, and biotech firms subsequently renegotiate the contract terms when equity market conditions improve and they can access external financing better equity market conditions as reflected in IPO volume and pricing. In short, Lerner, Shane, and Tsai suggest that contracting with Big Pharma and external financing via initial public offerings are imperfect substitutes whose relative costs and benefits vary with equity market cycles. Our results suggest that external contracting activity can also serve as a complement to a biotech's efforts to raise equity capital via PIPE deals in years subsequent to a firm's IPO.

Our findings are particularly relevant in the recent adverse economic climate. Public equity markets are periodically not receptive to new issues of equity by biotech firms, and large cash rich pharmaceutical companies look to acquire smaller R\&D firms opportunistically or enter into licensing and development contracts at terms more favorable to them and less favorable to the younger firms (Note 5). In such environments ' cash-hungry biotech firms looking to obtain financing yet retain independence are likely to turn increasingly to PIPE deals as an important counterbalance to the negotiating power and cash resources of Big Pharma.

The rest of this paper is organized as follows. Section 2 describes our sample of biotech firms and documents their financing and contracting activity. Section 3 presents our analysis of how PIPE terms are influenced by firm-specific factors, including contracting activity. Section 4 concludes.

\section{Sample of Biotech Firms and Description of Financing and Contracting Activity}

\subsection{Sample Identification}

We identify all firms with SIC code 283 (drug-related businesses) that experienced their initial public offerings of common stock between during July 1996 to December 2004. Data sources include Professor Jay Ritter's IPO database of US IPOs for 1980 to 2000, the SDC IPO database for 1996 to 2004, and the CRSP database. For all seeming IPOs for firms in the 283 SIC code we then search the SEC's EDGAR online database for company filings (IPO prospectuses, in particular), based on which we decide whether or not a newly listed firm is indeed an IPO as opposed to the result of the reorganization of an already public firm (Note 6). For confirmed IPOs during the sample period, we also cross check the accuracy of SIC code listed in the three data sources listed above against the SIC code listed in the prospectus. We find that on occasions the SIC code listed on the prospectus do not match the SIC code in those three databases. When such conflicts occur we rely on the SIC code in the prospectus. As is commonly done in the academic literature on IPOs, we exclude ADRs, unit offerings, and firms whose primary business location is outside the US (Note 7). This initial screen resulted in a total of 110 firms that experienced an IPO during July 1996 to December 2004 under the three-digit SIC code of 283. Table 1 provides basic description on timing and sizes of IPO of the sample firms.

Table 1. Descriptive statistics on sample firms that went public with SIC code 283 during July 1996 to December 2004 and these firms' PIPE financing activity in the following years (dollar figures in millions)

\begin{tabular}{|c|c|c|c|c|c|c|c|c|c|c|c|}
\hline Year & \# IPO & $\begin{array}{l}\text { Avg } \\
\text { IPO } \\
\text { size }\end{array}$ & $\begin{array}{l}\text { median } \\
\text { IPO size }\end{array}$ & $\begin{array}{c}\text { SUM } \\
\text { IPO size }\end{array}$ & $\begin{array}{c}\# \\
\text { conv. } \\
\text { PIPE }\end{array}$ & $\begin{array}{c}\text { \# common } \\
\text { stock } \\
\text { PIPE }\end{array}$ & $\begin{array}{c}\text { \# EFF } \\
\text { PIPE }\end{array}$ & $\begin{array}{l}\text { total \# } \\
\text { PIPE } \\
\text { deals }\end{array}$ & $\begin{array}{l}\text { avg. } \\
\text { \$ size }\end{array}$ & $\begin{array}{l}\text { med. } \\
\text { \$ size }\end{array}$ & $\begin{array}{c}\text { sum PIPE } \\
\$ \text { size }\end{array}$ \\
\hline 1996 & 12 & $\$ 31$ & $\$ 18$ & $\$ 367$ & --- & --- & --- & --- & --- & --- & --- \\
\hline 1997 & 18 & $\$ 26$ & $\$ 20$ & $\$ 471$ & 0 & 2 & 0 & 2 & $\$ 17$ & $\$ 17$ & $\$ 34$ \\
\hline 1998 & 8 & $\$ 45$ & $\$ 44$ & $\$ 360$ & 5 & 2 & 0 & 7 & $\$ 25$ & $\$ 15$ & $\$ 176$ \\
\hline 1999 & 6 & $\$ 48$ & $\$ 50$ & $\$ 288$ & 4 & 6 & 1 & 11 & $\$ 36$ & $\$ 14$ & $\$ 393$ \\
\hline 2000 & 25 & $\$ 55$ & $\$ 48$ & $\$ 1,382$ & 5 & 10 & 5 & 20 & $\$ 53$ & $\$ 43$ & $\$ 1,055$ \\
\hline 2001 & 3 & $\$ 82$ & $\$ 83$ & $\$ 247$ & 7 & 14 & 3 & 24 & $\$ 73$ & $\$ 26$ & $\$ 1,755$ \\
\hline 2002 & 3 & $\$ 148$ & $\$ 120$ & $\$ 445$ & 1 & 11 & 2 & 14 & $\$ 17$ & $\$ 14$ & $\$ 235$ \\
\hline 2003 & 9 & $\$ 50$ & $\$ 60$ & $\$ 449$ & 8 & 18 & 2 & 28 & $\$ 37$ & $\$ 18$ & $\$ 1,030$ \\
\hline 2004 & 26 & $\$ 58$ & $\$ 47$ & $\$ 1,500$ & 7 & 18 & 0 & 25 & $\$ 54$ & $\$ 18$ & $\$ 1,348$ \\
\hline 2005 & --- & --- & --- & --- & 7 & 15 & 4 & 26 & $\$ 60$ & $\$ 34$ & $\$ 1,556$ \\
\hline 2006 & --- & --- & --- & --- & 6 & 29 & 8 & 43 & $\$ 44$ & $\$ 30$ & $\$ 1,876$ \\
\hline total & 110 & $\$ 50$ & & $\$ 5,508$ & 50 & 125 & 25 & 200 & $\$ 47$ & & $\$ 9,458$ \\
\hline
\end{tabular}

Note. In table 1, data for 1996 only includes the second half of the year.

We see from Table 1 that total IPO proceeds of $\$ 5.5$ billion dollars were raised by these 110 firms through their initial public offerings. The number and size of IPOs vary across calendar years. Twenty-five firms with $\$ 1.38$ 
billion gross proceeds went public in 2000, the year US equity market was at its highest valuation until the end of 2006. There were only a handful of IPOs in 2001 to 2003 when US stock market was in a long slump. IPO activity picked up again with 26 new issues in year 2004 when the overall market started to recover. The fluctuation of IPO volume documented here within SIC code 283 is consistent with the existing literature on IPO volume and market conditions on broad samples (Benninga, Helmantel, \& Sarig, 2005).

\subsection{PIPE Financing Activity by Sample Firms}

For the 110 sample firms identified we collect information on PIPE deals from Sagient Research's PlacementTracker database, which has been used in several leading academic research studies on PIPE and is cited as the best source for PIPE information (Chaplinsky \& Haushalter, 2010). We search the PlacementTracker database using trading symbols of the sample firms and obtain dates of PIPE deals (Note 8). We then examine the SEC Edgar online database and search each firm's filings (10-K, 10-Q, 8-K, etc) for information regarding the PIPE deals.

We classify each deal into one of three broadly defined categories by security type. The first category is convertible securities, including various convertible debts and convertible preferred stocks (Note 9). The second category is common equity, including deals of common stock only, common stock plus warrants, and collaboration agreements with concurrent common stock investment by collaboration partners. Common stock PIPEs can be with or without warrants and are usually issued at discount to the prevailing price of publicly traded shares. When warrants are issued along with shares the warrant exercise price is usually at premium to current share price. The third category is a committed equity financing facility (CEFF). A CEFF offers a timing option and more flexibility to the issuing firm, and a CEFF normally consists of several installments called draw downs. At the close of an equity financing facility PIPE, the total dollar amount of the deal, the effective period, the general terms and the number (or frequency) of draw downs are agreed upon by the issuing firm and investors. The issuing firm decides when to issue a draw down notice to the investors. We separate CEFF deals from the common equity group because such deals normally have specific upper limits on amount of investments and specified periods during which the investing parties are entitled to several draw downs without predetermined dates and prices. As such, the timing, price, and amount of each draw down is not disclosed at deal close, and therefore cannot be studied in detail.

For deals involving shares of common stock we record the PIPE offer price per share and any disclosed discount or premium relative to recently public trading prices. We also record the stated use of funds raised, although most firms provide only general statements about the intended use of funds raised, such as that the offer proceeds will be used to fund clinical development and other research and development activities. Sometimes, however, specific drug candidates are identified, especially when they are in late-stage testing or close to FDA approval filing. On a few occasions, convertible debt is clearly purported for retiring existing indebtedness. Finally, we note whether the PIPE investors participate in the operations or governance of the offering firm. We classify the investors as participating when board membership is extended along with the investment, when the investors include senior managers of the offering firm, and when a private investor is collaboration partner with the offer firm (e.g., a licensing or co-marketing partner).

For our 110 sample firms that went public during July 1996 to December 2004, we find 61 firms (roughly 55\% of the IPO sample) have at least one PIPE deal, and these 61 firms have a total of 200 PIPE deals by the end of year 2006. The right hand panel in Table 1 shows the number and dollar value of the proceeds from these PIPE deals by type and calendar year. Unlike the public financing that was greatly affected by the stock market in years 2001 to 2003 , the private financing activity remained strong during that time period. The total of $\$ 9.5$ billion dollars raised via the 200 PIPE deals by the end of 2006 almost doubles the total IPO proceeds raised by all SIC-code 282 firms over the 1996-2004 period.

Table 2 provides the frequency and descriptive statistics on 200 PIPE deals by deal type. There are 50 convertible PIPE deals with average (median) size of $\$ 100.1$ (\$50.0) million, 125 common stock deals with average (median) size of $\$ 26.8$ (\$20.0) million, and $25 \mathrm{CEFF}$ (committed equity financing facility) with average (median) deal size of $\$ 44.2$ (\$45.0) million dollars. Among the 125 common stock deals, 76 are stock-only deals and the other 49 deals include warrants. We provide more details on the terms of these 125 stock deals below. 
Table 2. Descriptive statistics on size of PIPE deals (in millions of US \$) by deal type

\begin{tabular}{lcccccc}
\hline Deal type & $\mathrm{N}$ & average & std. & max. & median & min. \\
\hline Convertibles & 50 & $\$ 100.1$ & $\$ 124.9$ & $\$ 500.0$ & $\$ 50.0$ & $\$ 1.0$ \\
Common stock & 125 & $\$ 26.8$ & $\$ 26.4$ & $\$ 175.0$ & $\$ 20.0$ & $\$ 1.9$ \\
Equity financing facility & 25 & $\$ 44.2$ & $\$ 27.0$ & $\$ 100.0$ & $\$ 45.0$ & $\$ 8.0$ \\
\hline
\end{tabular}

Figure 1 shows that the distribution of PIPE deals across firms ranges from one to ten deals per firm. Out of the 61 firms that have PIPE financing, 47 firms have had one to four deals (15 firms with one deal, 15 firms with two, ten firms with three, and seven firms with four) done during the sample period. The rest 14 firms each have from five to ten PIPE deals (one firm with ten deals, two firms with nine, and two firms with eight). Since the length of public trading history varies among the sample firms, with the longest of 9.5 years and shortest of just two years, it is difficult to relate number of PIPE deals to firm-specific characteristics. Figure 2 and Figure 3 depict the number and dollar amount of PIPE deals in terms of number of years since the firms' IPO date.

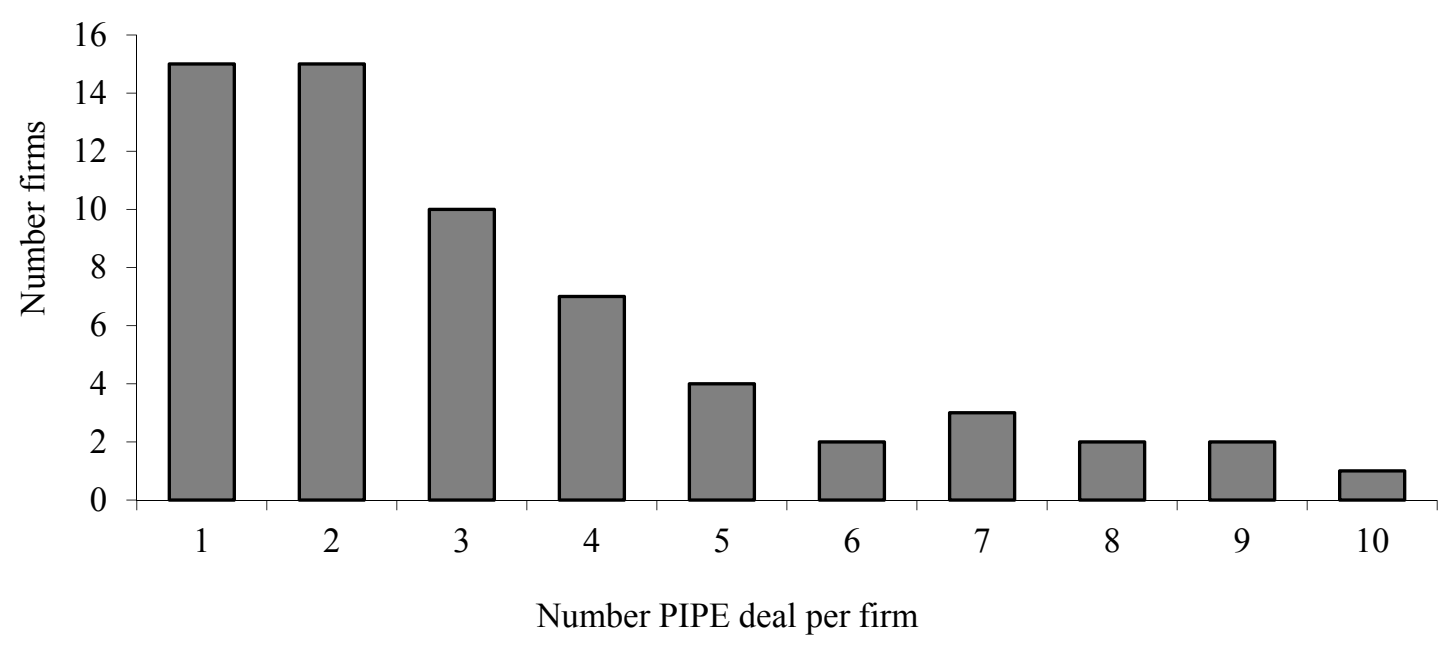

Figure 1. Number of firms vs. number of PIPE deals

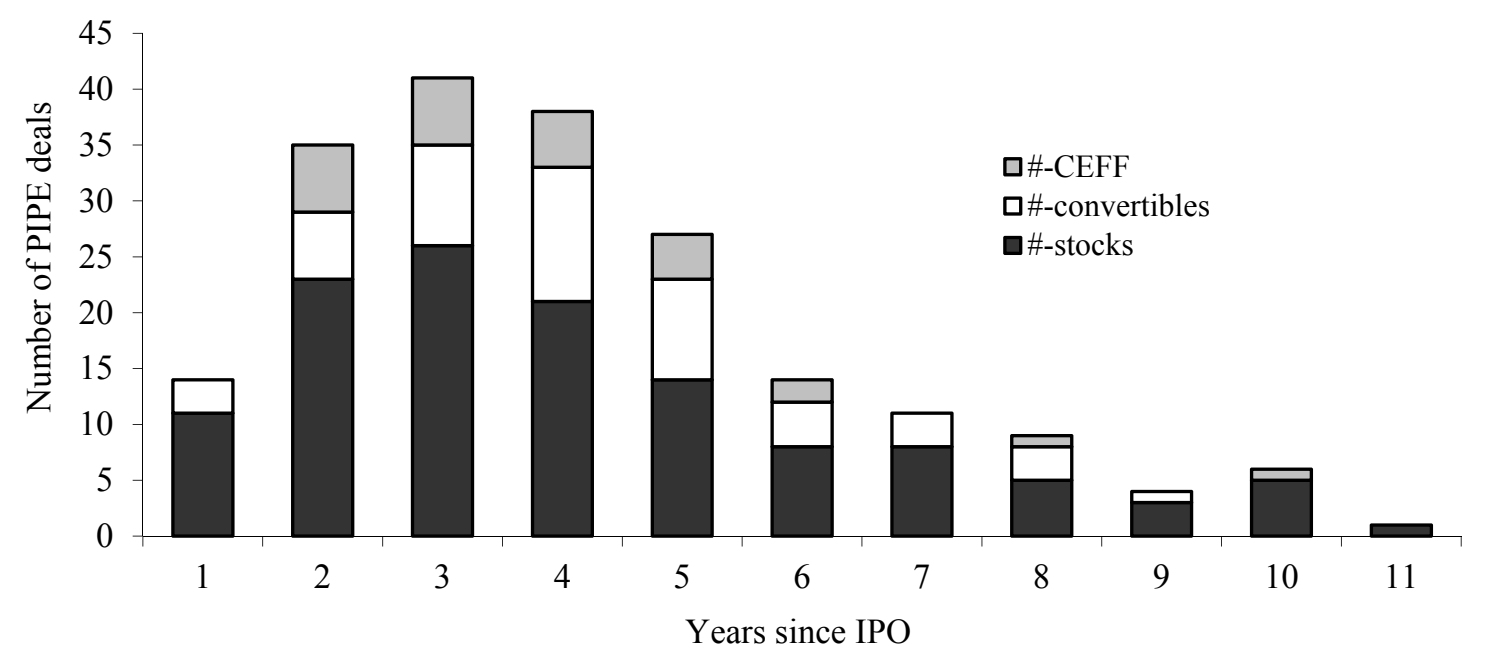

Figure 2. Number of PIPE deals vs. timing of deal in number of years since IPO 


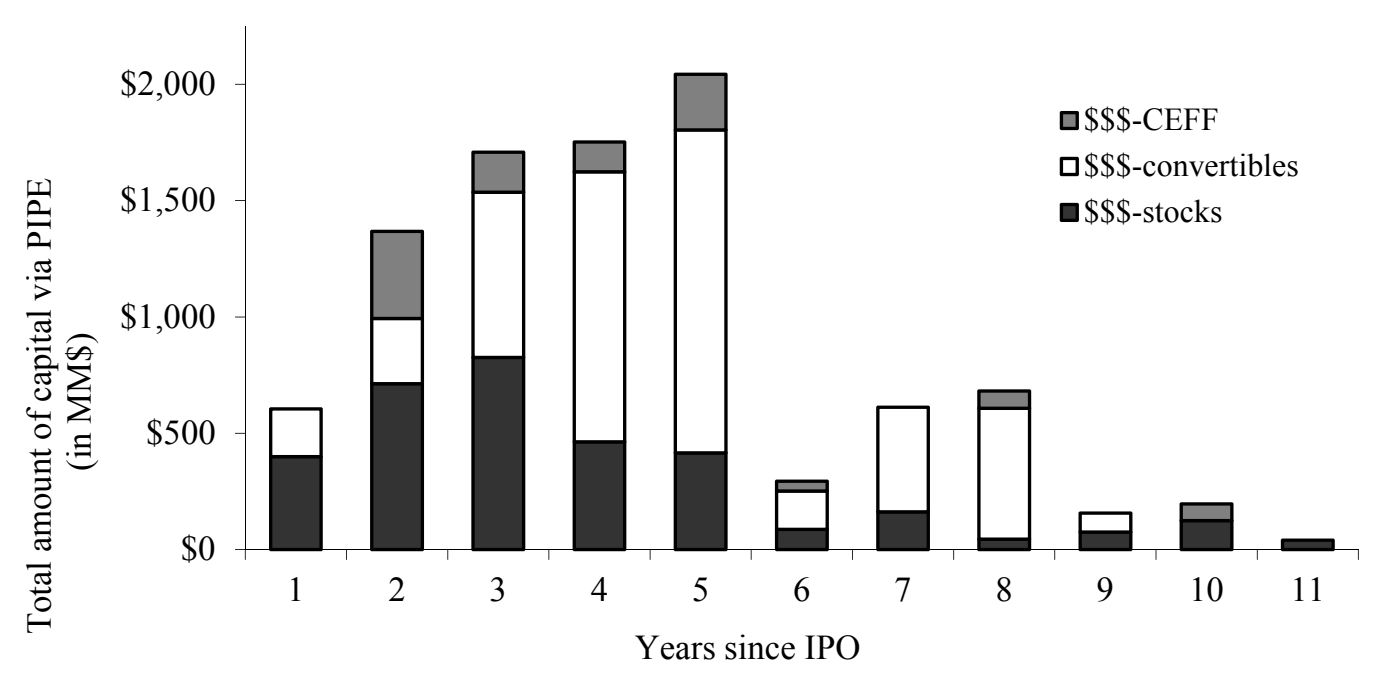

Figure 3. Capital raised via PIPE vs. timing of deal within number of years of IPO

Table 3 provides information on firms' characteristics during the 120 trading days before PIPE deal announcement. The choices of these measures are all common practice in prior academic literature and will be discussed in the following section as they relate to terms of PIPE investments. The descriptive statistics are organized into three panels, the top panel includes all 200 PIPE deal, the middle panel covers the first PIPE deal of any type for each of the 61 firms, and the bottom panel only considers the first common stock deal for 50 out of the 61 firms since 11 firms do not have PIPE that involve out right stock purchase. Table 3 suggests that the sample firm are small, and the mean (median) market capitalization for all 200 deals, 61 first deals of any type, and 50 first stock deals are, \$356 M (\$164 M), \$385 M (\$164 M), and \$229 M (\$162 M), respectively. The trading volatility measured by mean daily absolute returns are comparable across the three panels with means (medians) of, 3.62\% (3.33\%) for all 200 deals, 3.48\% (3.27\%) for 61 first deals of any type, and 3.71\% (3.60\%) for 50 first stock deals. These volatility figures are relatively high in both absolute terms and in comparison to broad market averages. The daily turnover, measured by average daily number of shares traded over total number of shares outstanding during the 120 trading days before PIPE announcements, decreases from the top panel to the bottom, with means (medians) of $1.16 \%(0.66 \%)$ for all 200 deals, $1.03 \%(0.46 \%)$ for 61 first deals of any type, and $0.80 \%(0.51 \%)$ for 50 first stock deals. The difference between the top and bottom panel (i.e., all 200 deals vs. 50 first time stock deals) is likely due to multiple PIPE deals by some sample firms that have higher turnover and greater market capitalization.

Table 3. Descriptive statistics on sample firms pre-PIPE deals (all measures are based on averages of daily figures over the 120 trading day pre-deal period)

\begin{tabular}{|c|c|c|c|c|c|}
\hline A. All deals $(\mathrm{N}=200)$ & mean & std & $\mathrm{q} 3$ & median & $\mathrm{q} 1$ \\
\hline Market capitalization (in MM\$) & 355.8 & 833.2 & 322.7 & 164.2 & 95.2 \\
\hline volatility & $3.62 \%$ & $1.38 \%$ & $4.53 \%$ & $3.33 \%$ & $2.55 \%$ \\
\hline turnover & $1.16 \%$ & $2.11 \%$ & $1.23 \%$ & $0.66 \%$ & $0.38 \%$ \\
\hline cumulative raw return & $19.60 \%$ & $58.52 \%$ & $48.62 \%$ & $12.44 \%$ & $-16.94 \%$ \\
\hline cumulative Biotech index adjusted return & $9.61 \%$ & $48.91 \%$ & $33.00 \%$ & $9.18 \%$ & $-22.52 \%$ \\
\hline cumulative market adjusted return & $8.61 \%$ & $53.64 \%$ & $30.96 \%$ & $3.98 \%$ & $-25.81 \%$ \\
\hline PIPE deal size (in MM\$) & $\$ 47.3$ & $\$ 73.0$ & $\$ 50.0$ & $\$ 25.0$ & $\$ 12.0$ \\
\hline relative PIPE deal size to IPO & $146.5 \%$ & $191.1 \%$ & $178.6 \%$ & $73.2 \%$ & $33.7 \%$ \\
\hline relative PIPE deal size to mean mktcap 120 days before & $20.5 \%$ & $26.6 \%$ & $24.4 \%$ & $14.3 \%$ & $8.8 \%$ \\
\hline
\end{tabular}




\begin{tabular}{|c|c|c|c|c|c|}
\hline B. First deal of any kind for each firm $(\mathrm{N}=61)$ & mean & std & $\mathrm{q} 3$ & median & $\mathrm{q} 1$ \\
\hline Market capitalization (in MM\$) & $\$ 385.0$ & $\$ 1,175.2$ & $\$ 326.6$ & $\$ 163.7$ & $\$ 93.6$ \\
\hline volatility & $3.48 \%$ & $1.18 \%$ & $4.21 \%$ & $3.27 \%$ & $2.55 \%$ \\
\hline turnover & $1.03 \%$ & $3.26 \%$ & $0.73 \%$ & $0.46 \%$ & $0.28 \%$ \\
\hline cumulative raw return & $14.51 \%$ & $56.56 \%$ & $51.44 \%$ & $18.73 \%$ & $-26.93 \%$ \\
\hline cumulative Biotech index adjusted return & $6.89 \%$ & $50.94 \%$ & $40.36 \%$ & $7.92 \%$ & $-26.78 \%$ \\
\hline cumulative market adjusted return & $5.06 \%$ & $52.06 \%$ & $39.82 \%$ & $3.30 \%$ & $-33.31 \%$ \\
\hline PIPE deal size (in MM\$) & $\$ 47.3$ & $\$ 56.3$ & $\$ 60.0$ & $\$ 30.0$ & $\$ 14.9$ \\
\hline relative PIPE deal size to IPO & $135.1 \%$ & $152.5 \%$ & $151.5 \%$ & $78.1 \%$ & $34.1 \%$ \\
\hline relative PIPE deal size to mean mktcap 120 days before & $19.8 \%$ & $13.8 \%$ & $25.7 \%$ & $15.3 \%$ & $10.7 \%$ \\
\hline C. First stock deal $(\mathrm{N}=50)$ & mean & std & $\mathrm{q} 3$ & median & $\mathrm{q} 1$ \\
\hline Market capitalization (in MM\$) & $\$ 229.0$ & $\$ 193.7$ & $\$ 318.8$ & $\$ 162.5$ & $\$ 82.7$ \\
\hline volatility & $3.71 \%$ & $1.43 \%$ & $4.57 \%$ & $3.60 \%$ & $2.56 \%$ \\
\hline turnover & $0.80 \%$ & $1.14 \%$ & $0.83 \%$ & $0.51 \%$ & $0.27 \%$ \\
\hline cumulative raw return & $20.34 \%$ & $71.96 \%$ & $59.60 \%$ & $13.65 \%$ & $-32.68 \%$ \\
\hline cumulative Biotech index adjusted return & $11.47 \%$ & $58.88 \%$ & $55.01 \%$ & $9.54 \%$ & $-26.90 \%$ \\
\hline cumulative market adjusted return & $12.52 \%$ & $65.61 \%$ & $55.38 \%$ & $9.83 \%$ & $-34.68 \%$ \\
\hline PIPE deal size (in MM\$) & $\$ 33.7$ & $\$ 33.1$ & $\$ 50.0$ & $\$ 21.5$ & $\$ 11.5$ \\
\hline PIPE deal size relative to IPO & $107.8 \%$ & $128.2 \%$ & $135.0 \%$ & $57.5 \%$ & $33.3 \%$ \\
\hline PIPE deal size to mean mktcap -120 days & $18.4 \%$ & $14.7 \%$ & $25.7 \%$ & $14.0 \%$ & $8.6 \%$ \\
\hline
\end{tabular}

In terms of raw returns, biotech index adjusted returns, and CRSP equally-weighted market adjusted returns, all three panels of Table 3 show significant positive mean (median) cumulative returns over the 120 trading days before a PIPE deal's announcement. The mean (median) biotech index adjusted returns, for example, are, $9.61 \%$ (9.18\%) for all 200 deals, 6.89\% (7.92\%) for 61 first deals of any type, and $11.47 \%$ (9.54\%) for 50 first stock deals. Such consistent positive pre-deal returns suggest issuing firms tend to raise additional capital following good stock performance. This finding contrasts somewhat with general characterizations of PIPE deals previously reported. Specifically, broad samples of firms announcing PIPE deals tend to have poor prior stock price performance (Chaplinsky \& Haushalter, 2010; Barclay, Holderness, \& Sheehan, 2007). On the basis of similar evidence Gomes and Phillips (2012) suggest that private placements are less likely than SEOs to result from attempts to time financing to coincide with favorable stock prices. PIPE deals by biotech firms, in contrast, appear to follow stock price run-ups in a manner consistent with favorable market timing.

Table 4 describes the size and timing of the first stock deal measured in number of years since IPO. Among the 61 firms that engage in PIPE activity, 50 have stock deals, of which, 10 sought additional equity financing through PIPE during the very year they went public and 16 did so within 2 years of public trading. When we include all types of PIPE deals, 37 firms sought additional funding via PIPE within two years of IPO, which account for 34\% (37 over 110) of all newly public biotech firms. This figure seems in line with the expectation frequently stated in IPO prospectus that funds raised in the IPO provide enough capital for two to three years of operation.

Table 4. Descriptive statistics on firms' first equity PIPE deals relative to IPO size

\begin{tabular}{ccccccccc}
\hline \multicolumn{2}{l}{ A. Deal size in millions of dollars } & \multicolumn{1}{c}{} \\
\hline Year & $\mathrm{N}$ & avg & std & max & $\mathrm{q} 3$ & median & $\mathrm{q} 1$ & min \\
$\mathrm{IPO}+1$ & 10 & $\$ 36$ & $\$ 23$ & $\$ 76$ & $\$ 60$ & $\$ 28$ & $\$ 20$ & $\$ 4$ \\
$\mathrm{IPO}+2$ & 16 & $\$ 36$ & $\$ 41$ & $\$ 175$ & $\$ 43$ & $\$ 29$ & $\$ 13$ & $\$ 3$ \\
$\mathrm{IPO}+3$ & 13 & $\$ 35$ & $\$ 26$ & $\$ 77$ & $\$ 59$ & $\$ 25$ & $\$ 15$ & $\$ 2$ \\
$\mathrm{IPO}+4$ & 7 & $\$ 36$ & $\$ 46$ & $\$ 132$ & $\$ 60$ & $\$ 20$ & $\$ 6$ & $\$ 5$ \\
$\mathrm{IPO}+5$ & 3 & $\$ 11$ & $\$ 9$ & $\$ 21$ & $\$ 21$ & $\$ 8$ & $\$ 10$ \\
IPO+6 & 1 & $\$ 10$ & - & $\$ 10$ & $\$ 10$ & $\$ 10$ & $\$ 10$ & $\$ 10$ \\
All deals & 50 & $\$ 34$ & $\$ 33$ & $\$ 175$ & $\$ 50$ & $\$ 21$ & $\$ 12$ & $\$ 2$ \\
\hline
\end{tabular}




\begin{tabular}{|c|c|c|c|c|c|c|c|c|}
\hline \multicolumn{9}{|c|}{ B. Deal size relative to IPO size } \\
\hline Year & $\mathrm{N}$ & avg & std & $\max$ & q3 & median & q1 & $\min$ \\
\hline IPO+1 & 10 & $164 \%$ & $216 \%$ & $667 \%$ & $143 \%$ & $67 \%$ & $43 \%$ & $27 \%$ \\
\hline $\mathrm{IPO}+2$ & 16 & $87 \%$ & $66 \%$ & $220 \%$ & $124 \%$ & $71 \%$ & $40 \%$ & $8 \%$ \\
\hline $\mathrm{IPO}+3$ & 13 & $98 \%$ & $113 \%$ & $409 \%$ & $133 \%$ & $49 \%$ & $33 \%$ & $4 \%$ \\
\hline $\mathrm{IPO}+4$ & 7 & $140 \%$ & $124 \%$ & $352 \%$ & $250 \%$ & $135 \%$ & $29 \%$ & $13 \%$ \\
\hline $\mathrm{IPO}+5$ & 3 & $23 \%$ & $24 \%$ & $51 \%$ & $51 \%$ & $13 \%$ & $7 \%$ & $7 \%$ \\
\hline $\mathrm{IPO}+6$ & 1 & $33 \%$ & - & $33 \%$ & $33 \%$ & $33 \%$ & $33 \%$ & $33 \%$ \\
\hline All deals & 50 & $108 \%$ & $128 \%$ & $409 \%$ & $135 \%$ & $57 \%$ & $33 \%$ & $4 \%$ \\
\hline \multicolumn{9}{|c|}{ C. Deal size relative to average market capitalization in 120 -day before deal } \\
\hline Year & $\mathrm{N}$ & avg & std & $\max$ & $\mathrm{q} 3$ & median & $\mathrm{q} 1$ & $\min$ \\
\hline $\mathrm{IPO}+1$ & 10 & $16.8 \%$ & $11.0 \%$ & $43.5 \%$ & $17.4 \%$ & $13.7 \%$ & $11.5 \%$ & $4.5 \%$ \\
\hline $\mathrm{IPO}+2$ & 16 & $26.4 \%$ & $17.4 \%$ & $63.1 \%$ & $33.4 \%$ & $23.9 \%$ & $13.2 \%$ & $4.6 \%$ \\
\hline $\mathrm{IPO}+3$ & 13 & $17.6 \%$ & $14.3 \%$ & $52.9 \%$ & $19.1 \%$ & $14.5 \%$ & $6.6 \%$ & $2.4 \%$ \\
\hline $\mathrm{IPO}+4$ & 7 & $11.2 \%$ & $8.4 \%$ & $26.2 \%$ & $18.0 \%$ & $9.8 \%$ & $2.9 \%$ & $2.7 \%$ \\
\hline $\mathrm{IPO}+5$ & 3 & $6.4 \%$ & $5.6 \%$ & $12.2 \%$ & $12.2 \%$ & $6.1 \%$ & $0.9 \%$ & $0.9 \%$ \\
\hline $\mathrm{IPO}+6$ & 1 & $3.9 \%$ & - & $3.9 \%$ & $3.9 \%$ & $3.9 \%$ & $3.9 \%$ & $3.9 \%$ \\
\hline All deals & 50 & $18.4 \%$ & $14.7 \%$ & $63.1 \%$ & $25.7 \%$ & $14.0 \%$ & $8.6 \%$ & $0.9 \%$ \\
\hline
\end{tabular}

With regard to PIPE investors' involvement of issuing firms' operation, out of the 200 PIPE deals, only 44 (or $22 \%$ ) deals are classified as having some sort of investor participation with the issuing forms operations or governance; the other 156 deals (or 78\%) deals do not involve investors that we would categorize as involved in governance or operations.

\subsection{External Contracting Activity}

For young biotech firms without marketable products, external contracting with other firms - and especially Big Pharma - can serve as a vital source of cash as well as an externally valid indicator of firm viability. Prior research suggests that financing activity among such firms cannot be understood unless viewed jointly with external contracting activity.

We extract information on external contracting activity by sample firms from a database supplied by Recombinant Capital (aka Recap). Recap is a consulting firm that specializes in the bio-pharmaceutical sector. Its comprehensive database covers bio-pharmaceutical alliances, product development and sales, employment agreements, and company information. The database on contracts maintained by Recap has been widely used and highly regarded by leading researchers (e.g., Lerner, Shane, \& Tsai, 2003; Robinson \& Stuart, 2006, 2007).

For each contract, Recap identifies the parties involved in the contract and which party is identified as a "client" firm or an "R\&D" firm. A client firm is the one that pays the R\&D firm to perform certain tasks, and/or in case of licensing agreement, a client firm is the licensor whereas the R\&D firm is the licensee. Recap also identifies and classified the subject matter of the contract (Note 10). Some contracts are single-purpose deals, such as acquisition for stock, or a simple development or license contract, whereas the majority of contracts are categorized by Recap as multiple-subject contracts. Recap also provides the year and month of initial signing of a contract and indicates if the contract terms are amended at a later date. The specific terms amended are typically not provided, however. Recap frequently identifies the nominal dollar value of the contract, whether or not equity investment is involved, and royalty terms. Not all contracts are characterized by all such information, however.

For our 110 sample firms, one is not in the Recap database, the rest all have external contracting data (Note 11). A total of 1,969 contracts are found in Recap database for these 109 firms, of which 756 contracts (38.4\%) are initially signed before the IPO date; the other 1,213 contracts $(61.6 \%)$ are signed after the sample firms went public.

Table 5 shows the number of contracts signed by our sample firms by calendar year, along with the number and percentage of subsequent amendments/revision of these contracts. The reason we provide contract revision information is because Lerner, Shane, and Tsai (2003) relate stock market condition to biotech firms' external contracting terms and financing options. For our sample, due to limited time span and firms' age, we do not observe a clear pattern in contract revision across the years. 
Table 5. Number of contracts signed by sample firms by calendar year

\begin{tabular}{cccc}
\hline year & \# contracts signed & \# contracts later amended & $\%$ contracts amended \\
\hline$<1990$ & 11 & 8 & $72.7 \%$ \\
1990 & 8 & 4 & $50.0 \%$ \\
1991 & 5 & 3 & $60.0 \%$ \\
1992 & 22 & 14 & $63.6 \%$ \\
1993 & 22 & 10 & $45.5 \%$ \\
1994 & 45 & 18 & $40.0 \%$ \\
1995 & 62 & 33 & $53.2 \%$ \\
1996 & 105 & 40 & $38.1 \%$ \\
1997 & 122 & 40 & $32.8 \%$ \\
1998 & 158 & 55 & $34.8 \%$ \\
1999 & 169 & 49 & $29.0 \%$ \\
2000 & 199 & 37 & $18.6 \%$ \\
2001 & 209 & 50 & $23.9 \%$ \\
2002 & 189 & 38 & $20.1 \%$ \\
2003 & 172 & 34 & $19.8 \%$ \\
2004 & 155 & 20 & $12.9 \%$ \\
2005 & 145 & 11 & $7.6 \%$ \\
2006 & 171 & 6 & $3.5 \%$ \\
total & 1969 & 470 & $23.9 \%$ \\
\hline
\end{tabular}

Table 6 provides the number of firms and the number of contracts they signed during each one-year interval. On average, firms sign a couple contracts a year, and this pace is quite stable for ten years around IPO. Table 7 shows the descriptive statistics on sizes of the contracts in millions of dollars. Out of the 1,969 contracts in the sample, $728(\sim 37 \%)$ are with size information. The total value of identified contracting activity by our sample firms is close to $\$ 70$ billion dollars. This figure shows the prevalence and importance of external contracting not only to our sample firms, but also to the entire bio-pharmaceutical industry since the other contracting parties (vs. our sample firms) are typically firms in the same sector. For ten years around firms' IPO, the mean (median) contract size increases steadily. For instance, five years before IPO the mean (median) contract size is $\$ 6 \mathrm{M}(\$ 2$ $\mathrm{M})$, one year before IPO it's \$40 M $(\$ 12 \mathrm{M})$, one year post IPO it's \$46 M $(\$ 15 \mathrm{M})$, and five years post IPO it's $\$ 224 \mathrm{M}(\$ 59 \mathrm{M})$. It is clear that as firms survive and prosper their contracting activity expands.

Table 6. Number and timing (with respect to IPO) of external contracting activity

\begin{tabular}{ccccccc}
\hline $\begin{array}{c}\text { \# year wrt. } \\
\text { IPO }\end{array}$ & \# firms & $\begin{array}{c}\text { avg. } \# \\
\text { contracts }\end{array}$ & $\begin{array}{c}\text { std.\# } \\
\text { contracts }\end{array}$ & $\begin{array}{c}\text { total } \# \\
\text { contracts }\end{array}$ & $\begin{array}{c}\text { max \# } \\
\text { contracts }\end{array}$ & $\begin{array}{c}\text { med. \# } \\
\text { contracts }\end{array}$ \\
\hline$[-10,-6]$ & 42 & 3 & 2 & 105 & 11 & 2 \\
-5 & 34 & 2 & 1 & 56 & 5 & 1 \\
-4 & 50 & 2 & 1 & 80 & 4 & 1 \\
-3 & 63 & 2 & 1 & 115 & 7 & 1 \\
-2 & 76 & 2 & 1 & 168 & 8 & 2 \\
-1 & 83 & 3 & 2 & 231 & 12 & 2 \\
1 & 81 & 3 & 2 & 209 & 10 & 2 \\
2 & 75 & 3 & 3 & 234 & 18 & 2 \\
3 & 75 & 3 & 2 & 201 & 14 & 2 \\
4 & 49 & 3 & 2 & 140 & 10 & 2 \\
5 & 45 & 2 & 2 & 102 & 7 & 2 \\
\hline 6,10$]$ & 51 & 6 & 8 & 328 & 44 & 4 \\
\hline
\end{tabular}


Table 7. Descriptive statistics on contract size (in millions of US \$) by year relative to IPO

\begin{tabular}{|c|c|c|c|c|c|c|c|}
\hline \# year wrt. IPO & \# non-missing \$size & avg. size & std. & sum & $\max$ & med. & $\min$. \\
\hline$[-10,-6]$ & 37 & $\$ 18$ & $\$ 36$ & $\$ 666$ & $\$ 150$ & $\$ 2$ & $\$ 0.10$ \\
\hline-5 & 26 & $\$ 6$ & $\$ 11$ & $\$ 157$ & $\$ 40$ & $\$ 2$ & $\$ 0.10$ \\
\hline-3 & 49 & $\$ 15$ & $\$ 22$ & $\$ 738$ & $\$ 109$ & $\$ 5$ & $\$ 0.10$ \\
\hline-2 & 73 & $\$ 51$ & $\$ 143$ & $\$ 3,716$ & $\$ 760$ & $\$ 7$ & $\$ 0.10$ \\
\hline 1 & 63 & $\$ 46$ & $\$ 76$ & $\$ 2,895$ & $\$ 405$ & $\$ 15$ & $\$ 0.10$ \\
\hline 2 & 82 & $\$ 100$ & $\$ 222$ & $\$ 8,175$ & $\$ 1,500$ & $\$ 20$ & $\$ 0.10$ \\
\hline 3 & 84 & $\$ 148$ & $\$ 389$ & $\$ 12,394$ & $\$ 2,500$ & $\$ 37$ & $\$ 0.10$ \\
\hline 4 & 35 & $\$ 105$ & $\$ 239$ & $\$ 3,659$ & $\$ 1,300$ & $\$ 28$ & $\$ 0.20$ \\
\hline 5 & 32 & $\$ 224$ & $\$ 425$ & $\$ 7,179$ & $\$ 1,900$ & $\$ 59$ & $\$ 0.20$ \\
\hline
\end{tabular}

Table 8 . Descriptive statistics on \% royalty terms of contracts by year relative to IPO

\begin{tabular}{|c|c|c|c|c|c|c|c|}
\hline \# year wrt. IPO & \# non-missing royalty & avg. \%royalty & std. & sum & $\max$ & med. & $\min$. \\
\hline$[-10,-6]$ & 17 & $13 \%$ & $21 \%$ & $217 \%$ & $66 \%$ & $4 \%$ & $1 \%$ \\
\hline-5 & 11 & $11 \%$ & $15 \%$ & $120 \%$ & $50 \%$ & $4 \%$ & $1 \%$ \\
\hline-4 & 22 & $14 \%$ & $18 \%$ & $316 \%$ & $60 \%$ & $6 \%$ & $2 \%$ \\
\hline-3 & 23 & $18 \%$ & $20 \%$ & $409 \%$ & $75 \%$ & $9 \%$ & $2 \%$ \\
\hline-2 & 31 & $14 \%$ & $16 \%$ & $449 \%$ & $50 \%$ & $7 \%$ & $1 \%$ \\
\hline-1 & 52 & $19 \%$ & $19 \%$ & $984 \%$ & $50 \%$ & $10 \%$ & $1 \%$ \\
\hline 1 & 14 & $21 \%$ & $18 \%$ & $295 \%$ & $50 \%$ & $11 \%$ & $2 \%$ \\
\hline 2 & 15 & $35 \%$ & $25 \%$ & $523 \%$ & $85 \%$ & $35 \%$ & $5 \%$ \\
\hline 3 & 19 & $33 \%$ & $20 \%$ & $620 \%$ & $65 \%$ & $40 \%$ & $5 \%$ \\
\hline 4 & 10 & $31 \%$ & $20 \%$ & $314 \%$ & $50 \%$ & $38 \%$ & $4 \%$ \\
\hline 5 & 4 & $29 \%$ & $13 \%$ & $114 \%$ & $45 \%$ & $27 \%$ & $15 \%$ \\
\hline$[6,10]$ & 16 & $21 \%$ & $16 \%$ & $340 \%$ & $50 \%$ & $19 \%$ & $1 \%$ \\
\hline total \# & 234 & & & & & & \\
\hline
\end{tabular}

Table 8 provides statistics on royalty terms of the contracts. 234 contracts (12\% of the entire 1969 contracts) have royalty provisions identified by Recap. Similar to the trend we observe in contract size, for ten years around firms IPO, the mean (median) percentage royalty also increases by year. Since we do not have the base amount to apply that royalty percentage to, where the base amount is normally the sales revenue of pharmaceutical product under development, it is not possible to estimate the potential impact across contracts. Nonetheless, we get a sense of the royalty terms, which generally fall into the range of $10-30 \%$.

Table 9 shows the role played by our sample firms in contracting activity. For each contract, RECAP identifies the two sides of the parties involved as either client or R\&D firm. The client firm is the one which outsources work to the R\&D firm. Out of 1,969 contracts by our sample firms, $645(\sim 33 \%)$ are as client firms, the rest 1324 $(67 \%)$ are as R\&D firms. Although not monotonic, the trend is that early in a firm's life cycle, it primarily functions as a R\&D shop. As a firm matures its business gets more complex and the need to outsource grows, and consequently, the relative number of contracts it signs as a client increases. Specifically, five years before IPO, 25\% of contracts are as client firms, whereas five years post IPO, $43 \%$ of contracts are as client firms.

Table 9. Sample firms' role in the contracts (as either client or R\&D firm) by year relative to IPO

\begin{tabular}{ccccc}
\hline \multirow{2}{*}{ \# year wrt. IPO } & \multicolumn{2}{c}{ \# contracts } & \multicolumn{2}{c}{$\%$ contract } \\
\cline { 2 - 5 } & Client & R\&D & Client & R\&D \\
\hline$[-10,-6]$ & 20 & 85 & $19.0 \%$ & $81.0 \%$ \\
-5 & 14 & 42 & $25.0 \%$ & $75.0 \%$ \\
-4 & 18 & 62 & $22.5 \%$ & $77.5 \%$ \\
-3 & 32 & 83 & $27.8 \%$ & $72.2 \%$ \\
\hline
\end{tabular}




\begin{tabular}{ccccc}
\hline-2 & 60 & 108 & $35.7 \%$ & $64.3 \%$ \\
-1 & 56 & 175 & $24.2 \%$ & $75.8 \%$ \\
1 & 82 & 127 & $39.2 \%$ & $60.8 \%$ \\
2 & 82 & 152 & $35.0 \%$ & $65.0 \%$ \\
3 & 74 & 127 & $36.8 \%$ & $63.2 \%$ \\
4 & 47 & 93 & $33.6 \%$ & $66.4 \%$ \\
5 & 44 & 58 & $43.1 \%$ & $56.9 \%$ \\
{$[6,10]$} & 116 & 212 & $35.4 \%$ & $64.6 \%$ \\
Total & 645 & 1324 & $32.8 \%$ & $67.2 \%$ \\
\hline
\end{tabular}

Table 10 provides contract subject information. Panel A shows the number of contracts that have one to eight subjects identified by RECAP for each contract. Panel B provides all subjects along with the number of contracts that fall into that subject. We see from Table 10 that "research", "development", "license", and "collaboration" are four popular contract types in both single- and multiple- type contracts.

In the following section we investigate how external contracting activity with other biotech firms conditions PIPE pricing. We measure the strength of firms' contracting network by number, type, and total size of their external contracts, and then investigate if contracting activity observed prior to the PIPEs deal conditions the offer price discount. We believe that external contracting activity proxies for the growth opportunities and business prospects of developmental firms. Thus our primary hypothesis is that biotech firms with stronger external contracting networks obtain better terms in PIPE deals as measured by smaller (less negative) offer price discounts.

\section{PIPE Pricing}

\subsection{Discounts in PIPE Offer Prices}

A key aspect of PIPE deals is that common stock is frequently offered to PIPE investors at a discount to the prevailing price of publicly traded common stock. Various studies investigate explanations for the prevalence and magnitude of discounts. Wruck (1989) proposes that the lower placement prices compensate private investors for costs incurred in monitoring the firm's activities subsequent to the PIPE offering. Barclay, Holderness, and Sheehan (2007), on the other hand, propose that issuing firms' managers intentionally give the discount to PIPE investors in exchange for subsequent passivity, a prediction that seems borne out in terms of subsequent governance activity. In contrast, Hertzel and Smith (1993) suggest that PIPE investors have to scrutinize an offering firm's business conditions before committing capital investment, and that the PIPE share discount compensates the investors' for their due diligence costs incurred prior to accepting the PIPE terms. Other factors that may explain PIPE discounts include share price volatility and liquidity, which can be viewed as costs of ownership for the private investors, and prior share price performance, which can be viewed as whether the firm has recently experienced bad news or poor performance and consequently has more difficulty in obtaining external capital through more traditional means such as an SEO or a debt offering.

Table 10. Descriptive statistics on contract subjects as identified by RECAP

Panel A. Number of contract subjects (total \# contracts $=1969$ )

\begin{tabular}{lcccccccc}
\hline \# type & 1 & 2 & 3 & 4 & 5 & 6 & 7 & 8 \\
\hline \# contracts & 809 & 535 & 342 & 190 & 55 & 28 & 7 & 3 \\
$\%$ contracts & $41.1 \%$ & $27.2 \%$ & $17.4 \%$ & $9.6 \%$ & $2.8 \%$ & $1.4 \%$ & $0.4 \%$ & $0.2 \%$ \\
\hline
\end{tabular}

Panel B. Contract subjects

\begin{tabular}{|c|c|c|c|c|c|c|c|c|}
\hline & \multicolumn{2}{|c|}{809 1-subject contracts } & \multicolumn{2}{|c|}{535 2-subject contracts } & \multicolumn{2}{|c|}{342 3-subject contracts } & \multicolumn{2}{|c|}{1904 -subject contracts } \\
\hline & \# contracts & $\%$ count & \# contracts & $\%$ count & \# contracts & $\%$ count & \# contracts & $\%$ count \\
\hline License & 320 & $39.6 \%$ & 317 & $59.3 \%$ & 295 & $86.3 \%$ & 177 & $93.2 \%$ \\
\hline Acquisition & 96 & $11.9 \%$ & 15 & $2.8 \%$ & 2 & $0.6 \%$ & 1 & $0.5 \%$ \\
\hline Supply & 83 & $10.3 \%$ & 76 & $14.2 \%$ & 44 & $12.9 \%$ & 34 & $17.9 \%$ \\
\hline Asset Purchase & 57 & $7.0 \%$ & 27 & $5.0 \%$ & 11 & $3.2 \%$ & 5 & $2.6 \%$ \\
\hline Distribution & 45 & $5.6 \%$ & 43 & $8.0 \%$ & 20 & $5.8 \%$ & 8 & $4.2 \%$ \\
\hline Research & 45 & $5.6 \%$ & 123 & $23.0 \%$ & 178 & $52.0 \%$ & 92 & $48.4 \%$ \\
\hline
\end{tabular}




\begin{tabular}{|c|c|c|c|c|c|c|c|c|}
\hline Manufacturing & 39 & $4.8 \%$ & 29 & $5.4 \%$ & 16 & $4.7 \%$ & 7 & $3.7 \%$ \\
\hline Collaboration & 27 & $3.3 \%$ & 100 & $18.7 \%$ & 144 & $42.1 \%$ & 98 & $51.6 \%$ \\
\hline Co-Promotion & 21 & $2.6 \%$ & 11 & $2.1 \%$ & 11 & $3.2 \%$ & 23 & $12.1 \%$ \\
\hline Development & 13 & $1.6 \%$ & 129 & $24.1 \%$ & 134 & $39.2 \%$ & 80 & $42.1 \%$ \\
\hline Equity & 10 & $1.2 \%$ & 58 & $10.8 \%$ & 47 & $13.7 \%$ & 75 & $39.5 \%$ \\
\hline Sublicense & 9 & $1.1 \%$ & 5 & $0.9 \%$ & 1 & $0.3 \%$ & 3 & $1.6 \%$ \\
\hline Settlement & 8 & $1.0 \%$ & 16 & $3.0 \%$ & 4 & $1.2 \%$ & 5 & $2.6 \%$ \\
\hline Cross-license & 6 & $0.7 \%$ & 4 & $0.7 \%$ & 2 & $0.6 \%$ & 3 & $1.6 \%$ \\
\hline Joint Venture & 5 & $0.6 \%$ & 4 & $0.7 \%$ & 2 & $0.6 \%$ & 4 & $2.1 \%$ \\
\hline Assignment & 4 & $0.5 \%$ & 5 & $0.9 \%$ & 5 & $1.5 \%$ & 5 & $2.6 \%$ \\
\hline Merger & 4 & $0.5 \%$ & 1 & $0.2 \%$ & 0 & $0.0 \%$ & 0 & $0.0 \%$ \\
\hline Option & 4 & $0.5 \%$ & 46 & $8.6 \%$ & 36 & $10.5 \%$ & 42 & $22.1 \%$ \\
\hline Warrant & 4 & $0.5 \%$ & 6 & $1.1 \%$ & 6 & $1.8 \%$ & 9 & $4.7 \%$ \\
\hline Marketing & 3 & $0.4 \%$ & 17 & $3.2 \%$ & 10 & $2.9 \%$ & 3 & $1.6 \%$ \\
\hline Co-Development & 2 & $0.2 \%$ & 8 & $1.5 \%$ & 18 & $5.3 \%$ & 38 & $20.0 \%$ \\
\hline Loan & 2 & $0.2 \%$ & 4 & $0.7 \%$ & 5 & $1.5 \%$ & 9 & $4.7 \%$ \\
\hline Co-Market & 1 & $0.1 \%$ & 1 & $0.2 \%$ & 2 & $0.6 \%$ & 2 & $1.1 \%$ \\
\hline Termination & 1 & $0.1 \%$ & 17 & $3.2 \%$ & 26 & $7.6 \%$ & 31 & $16.3 \%$ \\
\hline Letter of Intent & 0 & $0.0 \%$ & 8 & $1.5 \%$ & 6 & $1.8 \%$ & 6 & $3.2 \%$ \\
\hline Security & 0 & $0.0 \%$ & 0 & $0.0 \%$ & 1 & $0.3 \%$ & 0 & $0.0 \%$ \\
\hline
\end{tabular}

For all PIPE deals that fall into the category of common stock (include common stock only, and stock plus warrant deals), we calculate the PIPE discount as the percentage difference between PIPE investor purchase price per share relative to 30-day (10-day) average stock price before the deal announcement date. The choice of number of days is arbitrary, yet we feel that because of above average volatility of the sample, longer period averaging is warranted. Some studies merely use market price of one day (before or after), and others use average price over a period of days (Note 12). A negative number of PIPE discount means PIPE investors get the shares at discount to average pre-deal market price, whereas a positive numbers means PIPE investors actually pay a premium to average pre-deal market price (Note 13). A bigger PIPE discount translates into greater dilution of existing shareholders and a higher cost of capital for the issuing firm.

Table 11 provides descriptive statistics regarding PIPE discounts for stock-only deals and stock plus warrant deals. There are 76 stock-only deals, one with missing investor purchase price, reducing the sample size to 75 in panel A of Table 11. There are 49 stock plus warrant deals, one with missing purchase price and 10 with missing warrant exercise prices, thus reducing the sample sizes to 48 for PIPE discount measures and 39 for warrant exercise premium measures in panel B.

We know from previous research that PIPE placements are normally at discount to market prices. For instance, Chaplinsky and Haushalter (2010) report PIPE discount of (negative) 19.7\% for their broad based sample. Our results in Table 11, using 30- and 10-day pre-PIPE prices as benchmarks, show averages of $2.8 \%$ and $-2.4 \%$, and medians of $-2.3 \%$ and $-7.9 \%$ for 75 stock-only deals. The smaller PIPE discount in our sample, compared with previously reported figures, is probably due to the concentration of industry and the longer benchmark period over which we measure average market price.

Table 11. Descriptive statistics on PIPE discount (stock deals)

Panel A. 75 Stock-only deals, PIPE discount calculated as \%difference of purchase price to 30-day or 10-day avg. trading price

\begin{tabular}{lcccccccc}
\hline Discount to & avg & std & $\max$ & $\mathrm{q} 3$ & med & q1 & min & $\%$ positive \\
\hline 30-day av. price & $2.8 \%$ & $22.6 \%$ & $85.4 \%$ & $12.7 \%$ & $-2.2 \%$ & $-11.7 \%$ & $-26.7 \%$ & $42.7 \%$ \\
10-day av. price & $-2.4 \%$ & $18.6 \%$ & $77.0 \%$ & $2.6 \%$ & $-7.9 \%$ & $-12.9 \%$ & $-29.8 \%$ & $32.0 \%$ \\
\hline
\end{tabular}

Note. PIPE discount $30=$ PIPE investor purchase price per share / avg. 30 -day trading price -1 . PIPE discount $10=$ PIPE investor purchase price per share / avg. 10-day trading price -1 . 
Panel B. 48 Stock + warrant deals, PIPE discount calculated the same as stock only deals; also provided in this table are the warrant exercise price relative to purchase price (exe. Premium), exercise price to avg. 30-day \& 10-day trading prices (exe.prem30 \& exe.prem10)

\begin{tabular}{lcccccccc}
\hline Discount to & avg & std & $\max$ & $\mathrm{q} 3$ & med & q1 & min & $\%$ positive \\
\hline 30-day av. price & $-5.8 \%$ & $21.3 \%$ & $50.8 \%$ & $6.1 \%$ & $-6.4 \%$ & $-14.9 \%$ & $-71.8 \%$ & $39.6 \%$ \\
10-day av. price & $-7.8 \%$ & $14.9 \%$ & $27.4 \%$ & $0.9 \%$ & $-6.6 \%$ & $-16.7 \%$ & $-69.7 \%$ & $27.1 \%$ \\
exe. Prem. & $26.7 \%$ & $16.7 \%$ & $52.4 \%$ & $39.4 \%$ & $25.4 \%$ & $14.4 \%$ & $-2.2 \%$ & $87.2 \%$ \\
exe. Prem. 30 & $17.0 \%$ & $32.3 \%$ & $107.9 \%$ & $29.0 \%$ & $16.4 \%$ & $1.3 \%$ & $-66.2 \%$ & $76.9 \%$ \\
exe. Prem. 10 & $15.0 \%$ & $21.7 \%$ & $62.8 \%$ & $27.4 \%$ & $16.7 \%$ & $1.2 \%$ & $-63.6 \%$ & $79.5 \%$ \\
\hline
\end{tabular}

Note. Warrant exercise price data available for only 39 of the 48 deals.

Marciukaityte and Pennathur (2007) suggest that warrants serve as sweeteners in PIPE deals, and they appeal to optimistic investors in particular. Based on our sample, average discounts for deals with warrants do seem to be deeper than stock-only deals under both 30- and 10-day benchmarks (30-day average: -5.8\% with warrants vs. $2.8 \%$ without; 10-day average: $-7.8 \%$ with warrants vs. $-2.4 \%$ without). Median PIPE discounts present conflicting results, however. Ten-day benchmarking shows lower discounts for deals with warrants $(-6.6 \%)$ than without $(-7.9 \%)$. Thirty-day benchmarking gives the opposite comparison; deals with warrants have deeper discount $(-6.4 \%)$ than deals without warrants $(-2.2 \%)$. At this point the relation between warrants and PIPE discount is inconclusive pending regression results.

\subsection{Factors Hypothesized to Influence PIPE Discounts}

We identify a number of variables hypothesized to affect the level of estimated offer discounts among sample PIPE deals. The variables utilized are listed below with their hypothesized effects. Some of these variables are somewhat standard in the literature on private placement pricing (Wruck, 1989; Hertzel \& Smith, 1993; Wu, 2004; Gomes \& Phillips, 2012; Chaplinksy \& Haushalter, 2010; Meidan, 2006), but other variables are specific to our sample and the biotech industry, namely external contracting activity.

Participation. We construct an indicator variable for investor participation in the issuing firm's operations or governance. Wu (2004) and Barclay, Holderness, and Sheehan (2007) both show PIPE investors are generally passive and do not participate in firms' operations or monitoring, but when PIPE investors are active the deals are associated with lower discounts and better performance. Consequently, we also investigate whether PIPE investors pay higher prices (i.e. lower discount) to participate in a biotech firms' operations or governance.

Warrant financing. Finally, we also investigate whether the presence of warrants condition PIPE discounts for common equity offerings. We use an indicator variable for deals with warrants. Marciukaityte and Pennathur (2007) suggest that warrants tend to be associated with PIPE deals that attract overeager investors; ceteris paribus this might suggest that deals with warrants will have lower discounts. On the other hand, whether warrants are included with a deal is likely endogenous to other firm-specific characteristics that themselves may influence discounts in other ways.

Firm age. We use number of years since firms went public at deal close for firm age. US security law requires public firms to make value relevant information available and report on their business on at least a quarterly basis, but there is no such requirement for most private firms. Younger public firms, on average, should have higher information asymmetries compared with older ones. We expect older firms to sell PIPEs with lower discounts.

Firm size. We use the natural logarithm of average market capitalization during 120 trading prior to the PIPE deal announcement as a measure of firm size (Note 14). Smaller firms generally have higher information asymmetry compared to bigger firms. We anticipate negative relation between firm size and PIPE discount.

Analyst coverage. We use Thompson Financial's analyst recommendation database to obtain the number of analysts for each deal. We only count number of unique analysts that cover the issuing firm at any point before deal close. Analysts, seek information about the firms they cover and have relatively superior capability processing the information on the subject firms compared to general investing public. Firms with higher number of analysts should have lower information asymmetries. We expect negative relationship between number of analysts and PIPE discount, that is, higher number of analysts should be associated with higher purchase by PIPE investors.

Turnover. We use average daily turnover measured over 120 days before PIPE as proxy for liquidity. Since 
shares issued in PIPE cannot be traded immediately, investors should be compensated for a lack of liquidity via PIPE discount. Pre-PIPE liquidity directly affects the post PIPE era when shares are allowed to trade. Higher turnover suggests better liquidity and thus should be associated with higher placement prices.

Relative placement size. We compute PIPE deal amount relative to average market capitalization during the 120 days before the close of the PIPE deal. Previous research on block placement (Barclay, Holderness, \& Sheehan, 2001) shows that the relative size of the deal affects the price. Higher relative size means a larger portion of the firm is being sold and thus may have a larger impact on market price and liquidity when the newly issued shares are allowed to float in the secondary market. We anticipate a negative relation between relative placement size and PIPE share prices, i.e., larger placements have deeper discounts.

Volatility. We use mean daily absolute return over 120 days before PIPE deal as a measure of share price volatility. Higher volatility means less stable stock prices, which suggest higher degree of risk disposing the shares at desirable prices. Therefore, volatility should have negative impact on placement price, i.e., higher volatility leads to a larger discount.

Recent returns. We include two return measures in regressions. The first one is cumulative biotech index returns before PIPE, where we cumulate daily biotech index raw returns over the 120-day period before each deal's announcement date. This variable measures general equity market conditions in the biotech sector. The second measure is each firm's cumulative biotech index adjusted return over these 120 days. Each firm's own biotech index adjusted return reflects its performance relative to the sector return prior to the PIPE deal. We expect a positive relation between each measure of equity market conditions and the estimated PIPE discounts.

External contracting activity. It has been shown that external contracting has become an increasingly important method for organizing biotech firms' R\&D activity in recent years (Lerner et al., 2003; Robinson \& Stuart, 2006, 2007). The prevalence, size, and variety of contracting work by our sample firms are provided in Tables 5-9. We hypothesize a relation between firms' contracting activity and PIPE financing terms. For each of the equity deals, we aggregate the contracts firms signed during the 365-day period before deal close. We construct two variables for each PIPE deal: \# contracts, which is the total number of contracts during previous 365 days, and contract size, which is the total dollar amount of those contracts (Note 15).

Although the SEC does not have specific guidelines on disclosure of contracts, given the materiality of these contracts to young biotech firms, they normally release the general terms to the public. With each contract announced to the public, the investing community improves its understanding of the subject firm, so firms with higher number (size) of contracts should have lower information asymmetries. Also, PIPE investors frequently have access to non-public information as provide to them by the issuing firm, such as details of the contracts often marked confidential in SEC filings. Higher number (size) of contracts provides more information to the PIPE investors regarding firms' growth prospects, business connection with other firms, and revenue inflow. It is reasonable to expect that firms with higher number (size) of contracts have lower information asymmetry and better operational success. Hertzel and Smith (1993) suggest a PIPE discount is compensation for investors' due diligence required by high information asymmetry, thus, lower information asymmetry should result lower discount (higher prices). Based on this reasoning, we anticipate a positive relation between contracts and PIPE discount, that is, higher number (size) of contracts should be associated with higher placement prices (i.e. lower discounts).

We also tabulate the cumulative frequency of the four most popular contract types for these recent contracts, which are: research, development, license and collaboration. Our reason for including contract types is to check on their possible effect on PIPE terms. We do not have any specific a priori predictions regarding their effects.

\subsection{Regression Results}

Table 12 shows the regression results of various models with explanatory variables described in the prior section. The dependent variable is PIPE discount calculated as percent difference between investor purchase price per share divided by 30 -day average close price before deal announcement (Note 16). Regression results show that firm size, age, relative size of PIPE deals, number of analysts and recent biotech index returns, all have the expected signs, but none of these factors have significant impact on PIPE discount. Turnover is positively and significantly related to PIPE discount; this confirms that better trading liquidity lowers firms' cost of capital. Volatility is negatively and significantly linked to PIPE discount, as expected. With regard to warrants and PIPE terms model (6) shows an insignificantly negative coefficient. 
Table 12. Regression estimations for PIPE discounts (t-statistics beneath coefficient estimates)

\begin{tabular}{|c|c|c|c|c|c|c|}
\hline & $(1)$ & $(2)$ & (3) & (4) & $(5)$ & (6) \\
\hline \multirow[t]{2}{*}{ Intercept } & 0.0358 & 0.0599 & -0.0048 & 0.0032 & -0.0204 & -0.0030 \\
\hline & 0.19 & 0.32 & -0.03 & 0.02 & -0.36 & -0.05 \\
\hline \multirow[t]{2}{*}{ Turnover } & 4.2873 & 4.2773 & 3.9527 & 3.9648 & 4.0503 & 3.6354 \\
\hline & 2.22 & 2.21 & 2.07 & 2.07 & 2.36 & 2.07 \\
\hline \multirow[t]{2}{*}{ volatility } & -3.3940 & -3.3171 & -2.9115 & -2.9127 & -3.0204 & -3.1080 \\
\hline & -1.83 & -1.79 & -1.58 & -1.58 & -1.90 & -1.86 \\
\hline \multirow[t]{2}{*}{ ln_mktcap } & -0.0052 & -0.0121 & -0.0021 & -0.0041 & & \\
\hline & -0.17 & -0.39 & -0.07 & -0.13 & & \\
\hline \multirow[t]{2}{*}{$\%$ deal size } & -0.0043 & -0.0222 & -0.0157 & -0.0199 & & \\
\hline & -0.06 & -0.30 & -0.23 & -0.28 & & \\
\hline \multirow[t]{2}{*}{ age } & -0.0097 & -0.0130 & -0.0073 & -0.0083 & & \\
\hline & -0.98 & -1.24 & -0.75 & -0.78 & & \\
\hline \multirow[t]{2}{*}{ num. analyst } & 0.0061 & 0.0069 & 0.0033 & 0.0036 & & \\
\hline & 1.09 & 1.22 & 0.57 & 0.61 & & \\
\hline \multirow[t]{2}{*}{ participation } & 0.1510 & 0.1465 & 0.1340 & 0.1336 & 0.1389 & 0.1386 \\
\hline & 3.60 & 3.47 & 3.19 & 3.17 & 3.39 & 3.29 \\
\hline \multirow[t]{2}{*}{ bio. index ret. } & 0.0744 & 0.0820 & 0.0681 & 0.0704 & & \\
\hline & 0.76 & 0.84 & 0.71 & 0.73 & & \\
\hline \multirow[t]{2}{*}{ bio. Index adj. ret. } & 0.1365 & 0.1363 & 0.1319 & 0.1321 & 0.1328 & 0.1326 \\
\hline & 3.78 & 3.77 & 3.71 & 3.69 & 3.85 & 3.72 \\
\hline \multirow[t]{2}{*}{$\#$ contracts } & & 0.0130 & & 0.0034 & & \\
\hline & & 1.01 & & 0.25 & & \\
\hline \multirow[t]{2}{*}{ log contract size } & & & 0.0202 & 0.0193 & 0.0212 & 0.0197 \\
\hline & & & 2.19 & 1.95 & 2.42 & 1.94 \\
\hline \multirow[t]{2}{*}{ research } & & & & & & 0.0057 \\
\hline & & & & & & 0.13 \\
\hline \multirow[t]{2}{*}{ development } & & & & & & 0.0404 \\
\hline & & & & & & 1.14 \\
\hline \multirow[t]{2}{*}{ license } & & & & & & -0.0026 \\
\hline & & & & & & -0.13 \\
\hline \multirow[t]{2}{*}{ collaboration } & & & & & & -0.0409 \\
\hline & & & & & & -1.06 \\
\hline \multirow[t]{2}{*}{ warrant } & & & & & & -0.0219 \\
\hline & & & & & & -0.55 \\
\hline $\mathrm{N}$ & 123 & 123 & 123 & 123 & 123 & 123 \\
\hline $\mathrm{R}^{2}$ & 0.226 & 0.233 & 0.258 & 0.259 & 0.251 & 0.271 \\
\hline Adj. $R^{2}$ & 0.165 & 0.165 & 0.192 & 0.185 & 0.219 & 0.206 \\
\hline F Value & 3.67 & 3.41 & 3.9 & 3.52 & 7.82 & 4.16 \\
\hline Prob. $>$ F & 0.0005 & 0.0006 & 0.0001 & 0.0003 & $<.0001$ & $<.0001$ \\
\hline
\end{tabular}

Note. The dependent variable is the percentage difference between purchase price and the prior 30-day average price. Independent variables used in regression are: Turnover: average daily turnover over the 120 trading days pre PIPE announcement; volatility: average daily absolute return over the 120 trading days pre PIPE announcement; ln_mktcap: natural log of mean daily market cap over the 120 trading days before PIPE; \% deal size: PIPE deal size / avg. daily market cap. over the 120 trading days before PIPE - 1; age: number of years since firm went public; num. analyst: number of analyst covering the firm before PIPE announcement; participation: indicator variable $=1$ if PIPE deal involves board seat, management, or collaboration partnership; bio. index ret.: cumulative daily biotech index return over the 120 trading days pre PIPE announcements; bio. Index adj. ret.: issuing firm's cumulative daily biotech index adjusted return over the 120 trading days pre PIPE announcements; \# contracts: total number of contract the issuing firm signed in during 365 calendar days pre PIPE; log contract size: natural $\log$ of total contract size in millions of US $\$$ the issuing firm signed in during 365 calendar days pre PIPE; research: number of contracts that involves performing Research by the issuing firm during 365 calendar days pre PIPE; development: number of contracts that involves performing Development by the issuing firm during 365 calendar days pre PIPE; license: number of contracts that the issuing firm act as licensee during 365 calendar days pre PIPE; collaboration: number of contracts that involves collaboration of the issuing firm with others during 365 calendar days pre PIPE; warrant: indicator variable $=1$ if warrant is issued in the PIPE deal. 
The results in Table 12 indicate that the cumulative pre deal bio-index adjusted returns have significant positive coefficients in all models. This suggests PIPE deals following strong stock performance are at higher selling prices, which translate into lower cost of capital to issuing firms. These regression results provide strong evidence for firms' chasing the window of opportunity via PIPE deals.

Regarding investors' participation and financing terms, the regression results show positive and significant coefficient on the participation variable. The coefficient of 0.1389 in model (5) suggests that having PIPE investors participating in firms' operations or governance increases the ratio of placement price over market price by $13.89 \%$; in short, there appears to be a premium associated with assuming an operational or governance role with the biotech firm.

Regarding external contracting activity, log contract size has significant and positive coefficients, which suggests higher recent external contracting volume lead to higher PIPE placement prices. We find a similar result when we measure contract size as relative to a firm's market value of equity, although we do not report that in Table 12 . The sheer number of contracts, although it has positive coefficient as expected, is not significant. Indicator variables for various contract types are not significant either.

\section{Conclusions}

We study financing and external contracting activity at young biotech firms. For 110 firms that went public during July 1996 to December 2004 with the three-digit SIC industry code 283, a total of 61 firms raised additional capital via 200 PIPE deals by the end of 2006. Total capital raised in these PIPE deals ( $\$ 9.5$ billion) almost doubles the IPO proceeds of this sector ( $\$ 5.5$ billion). This additional financing activity by these firms starts as early as within one year of IPO. The average size of these PIPE deals is about $20 \%$ of issuing firms' pre-deal market capitalization. PIPE financing clearly plays a major role in the financing of these young biopharmaceutical firms.

On the operational side, we study our sample firms' external contracting activity. All but two of our 110 firms have extant contracting networks that date back as far as ten years before firms went public and that expand as firms grow and mature. Firms on average sign a couple contracts a year. The function of our sample firms in these contracts starts primarily as performing R\&D work for other outsourcing entities, and as these firms' vintage and the complexity of their business increase they gradually increase the percentage of contracts signed as client. The average size of the contracts also grows with the firms' life.

We find that strong pre-deal stock return is significantly related to lower offer price discounts in PIPE deals involving common equity. This result suggests that issuing firms exploit a window of opportunity by raising additional capital at favorable terms following stock price run ups. Investors' participation in issuing firms' operations or governance also has positive effect on private placement prices, suggesting a control premium in PIPE pricing. The structure of PIPE with respect to inclusion of warrants does not have significant impact offer price discounts.

We further link firms' external contracting activity to the financing terms they obtained in PIPE deals. We find that firms' with stronger contracting network, measured by bigger dollar value of contracts signed in the year prior to the PIPE deal, sell their stock at higher prices to private investors. A more valuable contracting network appears to lower the cost of external equity financing via PIPE deals for biotech firms. Lerner, Shane, and Tsai (2003) suggest that contracting with Big Pharma and external financing via initial public offerings are imperfect substitutes whose relative costs and benefits vary with equity market cycles. Our results suggest that external contracting activity can also serve as a complement to a biotech's efforts to raise equity capital via PIPE deals in years subsequent to a firm's IPO.

Our findings are particularly relevant in the recent adverse economic climate. Public equity markets are frequently not receptive to new issues of equity by biotech firms, and large cash rich pharmaceutical companies then look to acquire smaller R\&D firms opportunistically or enter into licensing and development contracts at terms more favorable to them and less favorable to the younger firms. In such an environment, cash-hungry biotech firms looking to obtain financing yet retain independence are likely to turn increasingly to PIPE deals as an important counterbalance to the negotiating power and cash resources of Big Pharma.

\section{References}

Allen, J., \& Phillips, G. (2000). Corporate equity ownership, strategic alliances, and product market relationships. Journal of Finance, 55(6), 2791-2815. http://dx.doi.org/10.1111/0022-1082.00307

Asquith, P., \& Mullins, D. (1986). Equity issues and offering dilution. Journal of Financial Economics, 15(1/2), 61-89. http://dx.doi.org/10.1016/0304-405X(86)90050-4 
Barclay, M. J., Holderness, C., \& Sheehand, D. (2001). The block pricing puzzle. Simon School of Business Working Paper No. FR 01-05.

Barclay, M. J., Holderness, C., \& Sheehand, D. (2007). Private placements and managerial entrenchment. Journal of Corporate Finance, 13(4) 461-484. http://dx.doi.org/10.1016/j.jcorpfin.2007.04.009

Bayless, M., \& Chaplinksy, S. (1996). Is there a window of opportunity for seasoned equity issuance? Journal of Finance, 51(1), 253-278. http://dx.doi.org/10.1111/j.1540-6261.1996.tb05209.x

Benninga, S., Helmantel, M., \& Sari, O. (2005). The timing of initial public offerings. Journal of Financial Economics, 75(1), 115-132. http://dx.doi.org/10.1016/j.jfineco.2003.04.002

Brophy, D. J., Ouimet, P.P., \& Sialm, C. (2007). Hedge funds as investors of last resort. Review of Financial Studies, 22(2), 541-574. http://dx.doi.org/10.1093/rfs/hhl045

Chaplinsky, S. J., \& Haushalter, D. (2010). Financing under extreme uncertainty: contract terms and returns to private investments in public equity. Review of Financial Studies, 23(7), 2789-2820. http://dx.doi.org/10.1093/rfs/hhq035

Choe, H., Masulia, R., \& Nanda, V. (1993). Common stock offerings across the business cycle: theory and evidence. Journal of Empirical Finance, 1(1), 3-33. http://dx.doi.org/10.1016/0927-5398(93)90003-A

Gomes, A. R., \& Phillips, G. (2012). Why do public firms issue private and public securities? Journal of Financial Intermediation, 21(4), 619-658. http://dx.doi.org/10.1016/j.jfi.2012.03.001

Guedj, I., \& Scharfstein, D. (2004). Organizational scope and investment: evidence from the drug development strategies and performance of biopharmaceutical firms. NBER working paper 10933.

Henderson, D. (2006). FDA rules aim to speed drug tests and trim cost. Boston Globe. Retrieved from http://www.boston.com/business/globe/articles/2006/01/13/fda_rules_aim_to_speed_drug_tests_and_trim_ costs/

Hertzel, M. G., \& Smith, R. L. (1993). Market discounts and shareholder gains for placing equity privately. Journal of Finance, 48(2), 459-485. http://dx.doi.org/10.1111/j.1540-6261.1993.tb04723.x

Hertzel, M. G., Lemmon, M., Linck, J., \& Rees, L. (2002). Long-run performance following private placement of equity. Journal of Finance, 57(6), 2595-2617. http://dx.doi.org/10.1111/1540-6261.00507

Hillion, P., \& Vermaelen, T. (2004). Death spiral convertibles. Journal of Financial Economics, 71(2), 381-415. http://dx.doi.org/10.1016/S0304-405X(03)00209-5

Hogboom, J. (2004). Private investment in public equity: an overview. New Jersey Law Journal.

Krishnamurthy, S., Spindt, P., Subramaniam, V., \& Woidtke, T. (2005). Does investor identity matter in equity issues? Evidence from private placements. Journal of Financial Intermediation, 14(2), 210-238. http://dx.doi.org/10.1016/j.jfi.2004.01.001

Lerner, J. (1994). Venture capitalists and the decision to go public. Journal of Financial Economics, 35(3), 293316. http://dx.doi.org/10.1016/0304-405X(94)90035-3

Lerner, J., Shane, S., \& Tsai, A. (2003). Do equity financing cycles matter? Evidence from biotechnology alliances. Journal of Financial Economics, $411-446$. http://dx.doi.org/10.1016/S0304-405X(02)00256-8

Marciukaityte, D., \& Pennathur, A. (2007). Equity with warrants in private placements. Financial Review, 42(1), 143-160. http://dx.doi.org/10.1111/j.1540-6288.2007.00165.x

Masulis, R. W., \& Korward, A. (1986). Seasoned equity offerings: an empirical investigation. Journal of Financial Economics, 15(1/2), 91-118. http://dx.doi.org/10.1016/0304-405X(86)90051-6

Meidan, D. (2006). The informativeness of offer characteristics versus investor identity in PIPE transactions. working paper. Retrieved from http://ssrn.com/abstract=894689

Myers, S. C., \& Majluf, N. (1984). Corporate financing and investment decisions when firms have information that investors do not have. Journal of Financial Economics, 13(2), 187-222. http://dx.doi.org/10.1016/0304-405X(84)90023-0

Robinson, D. T., \& Stuart, T. (2006). Network effects in the governance of strategic alliances. Journal of Law, Economics, and Organization, 23(1), 242-273. http://dx.doi.org/10.1093/jleo/ewm010

Robinson, D. T., \& Stuart, T. (2007). Financial contracting in biotech strategic alliances. Journal of Law and 
Economics, 50(3), 559-596. http://dx.doi.org/10.1086/519811

Sagient Research. (n.d.). Retrieved from http://www.PlacementTracker.com

Wruck, K. H. (1989). Equity ownership concentration and firm value. Journal of Financial Economics, 23(1), 328. http://dx.doi.org/10.1016/0304-405X(89)90003-2

Wu, Y. (2004). The choice of equity-selling mechanisms. Journal of Financial Economics, 74(1), 93-119. http://dx.doi.org/10.1016/j.jfineco.2003.08.003

\section{Notes}

Note 1. Academic studies of PIPEs and other forms of private placements include Wruck (1989), Hertzel and Smith (1993), Wu (2004), Meidan (2006), Chaplinsky and Haushalter (2006), and Brophy, Ouimet, Sialm (2007).

Note 2. See, for example, "It's alive! Meet one of biotech's zombies" by Andrew Pollack in the New York Times on Feb. 11, 2007.

Note 3. Entire 10-k filing. Retrieved from

http://www.sec.gov/Archives/edgar/data/1103390/000089161803001594/f88660e10vk.htm

Note 4. These nominal values do not usually represent merely cash flows between parties but rather extend to the conjectural value of licensing or distribution rights for products that may or may not ever reach market.

Note 5. For industry perspectives on the current financing climate for biotech firms please examine the following: Van Arnum, Patricia, 2009, A sobering PharmaChem outlook, PharmaTech.com, April 8, 2009; The best of times, the worst of times, Nature Biotechnology 27 (2), February 2009, p. 101.

Note 6 . The choice of our sample period is due to the availability of IPO prospectus via EDGAR online database which starts June 1996.

Note 7. During the sample period a total of three unit offers were made with SIC code 283.

Note 8. With respect to deal date, by comparing the dates provided by Sagient Research and SEC filings, it seems the date listed by Sagient Research are deal announcement dates rather than deal close date. Also, note that for firms that are later acquired, Sagient Research's database only displays numbers of PIPE deals without deal date information obtained via SEC filings.

Note 9. Convertibles with fixed conversion rate are called traditional PIPEs, whereas convertibles with flexible conversion rate are called structured PIPEs. Structured PIPEs are sometimes referred to as "death spirals" since their very design of the contract compensates private investors with higher percentage ownership stakes when stock price falls, thus diluting the stakes of other shareholders (Hillion and Vermaelen, 2004). Structured PIPEs appear to be decline both in number of deals and deal amount in recent years.

Note 10. For instance, Recap documents the contract between NIAID (National Institute of Allergy and Infectious Diseases), as the client and GenVec (one of our sample firms) as the research firm. This particular contract is classified by Recap as a development and licensing agreement. The subject for this contract reads as "Adenovector technology for AIDS vaccine."

Note 11. CN Biosciences (covered by CRSP during October 2, 1996 to December 30, 1998), is not in Recap contracting database, and International Isotope (in CRSP from August 14, 1997 to April 10, 2001) only has one contract in Recap.

Note 12. The predominance of discounts as measured by alternative methods is shown in several studies. Meidan (2006) calculates the PIPE discount based on market price one-day before deal close or announcement day. Wruck (1989) also use pre PIPE deal market price to calculate discount/premium. Hertzel and Smith (1993) and Krishnamurthy, Spindt, Subramaniam, and Woidtke (2005) use prices 10 day after PIPE.

Note 13. We maintain the convention of representing a discount as a negative number in all our tables and analysis. Some other studies reverse the signs so that discounts are positive numbers and premiums negative numbers.

Note 14. Other common measures of firm size - such as total assets, total revenues, or number of employees are not very informative in the biotech sector, especially among young firms without marketed products.

Note 15 . A third variable, dollar value of contracting activity relative to market capitalization, performs similarly 
to the total dollar value of contracting as reported in subsequent empirical analysis.

Note 16. Regressions using 10-day average price as benchmark for PIPE discount yield similar results.

\section{Copyrights}

Copyright for this article is retained by the author(s), with first publication rights granted to the journal.

This is an open-access article distributed under the terms and conditions of the Creative Commons Attribution license (http://creativecommons.org/licenses/by/3.0/). 